\title{
AKTSAR
}

ISSN 2622-5255 (online)

Volume 1 Nomor 2, Desember 2018, Halaman 155 - 170

ISSN 2622-2345 (cetak)

\section{Pengaruh Profitabilitas dan Firm Size Terhadap Firm Value dengan Capital Structure Sebagai Variabel Mediasi}

\author{
Andri Veno \\ Universitas Muhammadiyah Surakarta \\ veno.focus@gmail.com \\ Muslim Marpaung \\ Politeknik Negeri Medan \\ muslim.marpaung07@gmail.com
}

\begin{abstract}
This study aims to analyze the effect of profitability and firm size on firm value mediated by capital structure. The research design was a comparative causal approach (ex post facto) by testing the hypothesis analysis carried out using the component-based Structural Equation Modeling (SEM) method or non-parametric variance (Component Based SEM), Generalized Structured Component Analysis (GSCA). The data was collected from companies listed on the Indonesia Stock Exchange which are included in the LQ-45 index from 2014 until August 2018. In analyzing the data, the writers used multiple linear regression using the assistance of the GSCA program. The result showed that capital structure is proved as an intervening variable for the influence of profitability on firm value. It means that capital structure mediates the effect of profitability on firm value in full mediation. Meanwhile, capital structure is not an intervening variable for the influence of firm size on firm value. The Capital structure does not mediate the effect of firm size on firm value in full mediation.
\end{abstract}

Keywords: Profitability; Firm size; Firm value; Capital structure; Generalized structured component analysis (GSCA) 


\begin{abstract}
ABSTRAK
Penelitian ini bertujuan untuk mengetahui analisis pengaruh profitabilitas dan firm size terhadap firm value dengan dimediasi oleh variabel capital structure. Desain dalam penelitian ini mengunakan pendekatan mengunakan kausal komparatif (ex post facto ) dengan pengujian analisis hipotesis yang dilakukan menggunakan metode Structural Equation Modeling (SEM) berbasis component atau variance (Component Based SEM) yang bersifat non-parametrik yaitu Generalized Structured Component Analysis (GSCA), perusahaan yang terdaftar di Bursa Efek Indonesia yang masuk dalam kategori LQ-45 yang secara khusus diambil dari Indonesian Capital Market Directory (ICMD) dan Annual Report pada tahun 2014 sampai bulan Agustus 2018. Teknik analisis menggunakan analisis regresi linier berganda dengan menggunakan bantuan program GSCA. Hasil dari penelitian ini secara seluruhan menyatakan bahwa capital structure merupakan variabel intervening bagi pengaruh profitabilitas terhadap firm value, artinya capital structure memediasi pengaruh profitabilitas terhadap firm value secara full mediasi. Sedangkan capital structure merupakan bukan variabel intervening bagi pengaruh firm size terhadap firm value, artinya capital structure tidak memediasi pengaruh firm size terhadap firm value secara full mediasi.
\end{abstract}

Kata kunci: Profitabilitas; Ukuran Perusahaan; Nilai perusahaan; Struktur Modal; Generalized Structured Component Analysis (GSCA)

\title{
PENDAHULUAN
}

Nilai perusahaan merupakan informasi gambaran penting bagi pengambilan keputusan investor dalam mempertimbangkan langkah dalam berinvestasi dan pertumbuhan ekonomi merupakan wacana isu pokok dalam perekonomian suatu negara. Pemerintah melalui berbagai kebijakan berusaha untuk mencapai dan mempertahankan target pertumbuhan ekonomi Indonesia diatas 6\% pertahun. Keputusan keuangan adalah sebuah faktor utama bagi setiap perusahaan bisnis yang harus diperhatiakan baik pada saat mulai maupun selama operasional. Keputusan ini akan memiliki efek bagaimana perusahaan dapat bertahan (survival) dan stabilitas keadaan bisnis (Foyeke, Olusola, dan Aderemi, 2016). Dalam suatu bisnis, baik yang bergerak dalam bidang jasa maupun produksi selalu menginginkan agar usahanya dikelola dengan baik. Namun, tidak semua manajer mampu mengelola usahanya dengan baik. Dengan manajemen yang baik tentunya perusahaan akan memperoleh keuntungan, sehingga perusahaan akan mampu mengembangkan usahanya dan beroperasi secara terus menerus (Febriyani, 2010).

Pasar Modal merupakan tempat atau wadah yang digunakan untuk melakukan transaksi jual dan/atau beli efek serta menjadi sarana yang efektif guna melihat perkembangan sebuah perusahaan. Pasar modal juga merupakan sarana yang digunakan masyarakat untuk melakukan investasi jangka panjang sehingga dana 
investasi masyarakat dapat disalurkan ke sektor-sektor produktif. Perkembangan Pasar modal di Indonesia memberikan bukti bahwa pasar modal menjadi alternatif investasi bagi masyarakat Indonesia. Undang-undang Nomor 8 Tahun 1995 tentang Pasar Modal menyatakan bahwa Pasar Modal mempunyai peran yang strategis dalam pembangunan nasional sebagai salah satu sumber pembiayaan bagi dunia usaha dan wahana investasi bagi masyarakat.

Keuntungan bagi perusahaan yang masuk dalam Indeks LQ-45 yaitu para pelaku pasar modal telah mengakui dan mempercayai bahwa perusahaan memiliki tingkat likuditas dan kapitalisasi pasar yang baik, serta memiliki prospek yang baik dimasa yang akan datang sehingga mendorong peningatan harga saham ke arah positif. Bursa Efek Indonesia (2010) menyatakan bahwa kriteria suatu emiten untuk dapat masuk dalam perhitungan indeks LQ-45 adalah mempertimbangkan faktorfaktor seperti telah tercatat di BEI minimal 3 bulan, aktivitas transaksi di pasar reguler yaitu nilai, volume dan frekuensi transaksi, jumlah hari perdagangan di pasar reguler, kapitalisasi pasar pada periode waktu tertentu, serta keadaan keuangan dan prospek pertumbuhan perusahaan tersebut.

Struktur modal yang optimal suatu perusahaan adalah kombinasi dari utang dan ekuitas (sumber eksternal) yang memaksimumkan harga saham perusahaan. Pada saat tertentu, manajemen perusahaan menetapkan struktur modal yang ditargetkan, yang mungkin merupakan struktur yang optimal, meskipun target tersebut dapat berubah dari waktu ke waktu. Sejumlah faktor mempengaruhi keputusan mengenai struktur modal perusahaan, seperti stabilitas penjualan, struktur aktiva, leverage operasi, peluang pertumbuhan, tingkat profitabilitas, pajak penghasilan, tindakan manajemen dan sebagainya. Faktor-faktor lain yang mempengaruhi struktur modal perusahaan adalah ukuran perusahaan, perusahaan yang lebih besar pada umumnya lebih mudah memperoleh pinjaman dibandingkan dengan perusahaan kecil. Oleh sebab itu dengan memperoleh pinjaman perusahaan dapat berkembang lebih baik lagi (Umar Mai, 2006: 229).

Profitabilitas merupakan kemampuan perusahaan dalam memperoleh laba, rasio yang dapat digunakan untuk mengukur tingkat laba perusahaan adalah rasio profitabilitas, Kasmir (2008) yang dikutip oleh Suryanata, Suwendra, dan Yudiaatmaja, (2014) menyatakan "rasio profitabilitas merupakan rasio untuk menilai kemampuan perusahaan dalam mencari keuntungan". Ahmad (2016) menyatakan bahwa Profitabilitas dan liquiditas adalah dua variabel penting yang akan memberikan informasi mengenai kinerja dari keberadaan banyak bisnis/perusahaan. Untuk ketahanan (survival) jangka panjang dan pertumbuhan yang sehat keduanya, yaitu profitabilitas dan likuiditas harus berjalan/ bergerak maju/meningkat secara parallel satu sama lain. Profitabilitas adalahsalah satu tujuan utama keberhasilan kebanyakan setiap bisnis atau perusahaan. Tanpa menjadi untung (profitable) tidaklah mungkin untuk sebuah perusahaan untuk bertahan (survive) dan perusahaan akan susah untuk tumbuh (growth).

Besar kecilnya sebuah perusahaan adalah dengan ukuran aktiva dari perusahaan sebagai tolak ukur hal tersebut. Total aktiva besar yang dimiliki perusahaan menunjukkan bahwa perusahaan tersebut telah mencapai tahap kedewasaan dimana dalam tahap ini arus kas perusahaan sudah positif dan dianggap memiliki prospek yang baik dalam jangka waktu yang relatif lama, selain itu juga 
mencerminkan bahwa perusahaan relatif lebih stabil dan lebih mampu menghasilkan laba dibanding perusahaan dengan total asset yang kecil. Secara teoritis perusahaan yang lebih besar mempunyai kepastian (certainty) yang lebih besar daripada perusahaan kecil sehingga akan mengurangi tingkat ketidakpastian mengenai prospek perusahaan ke depan. Ukuran perusahaan dapat menentukan tingkat kepercayaan investor, dengan semakin besar perusahaan, maka akan semakin dikenal dan diketahui oleh masyarakat luas yang artinya semakin mudahnya untuk mendapatkan informasi yang akan meningkatkan nilai perusahaan. Pada dasarnya ukuran perusahaan hanya terbagi dalam kategori yaitu besar, sedang, dan kecil.(Tulus Prijanto, Andri veno dan chuzaimah, 2017).

Berdasarkan permasalahan yang ada, guna menegaskan secara operasional maupun untuk mempermudah focus penelitian, maka penelitian ini dibatasi pada pemilihan variable bebas Profitability (diproksikan oleh ROE), Frim size (diproksikan Asset), dan struktur modal (diproksikan oleh DER), dimana pemilihan variable dan proksi yang diteliti didasari oleh kajian penelitian-penelitian sebelumnya. Pembatasan pada pemilihan perusahaan yang masuk dalam indek LQ-45 juga didasari alasan karena indek LQ-45 merupakan salah satu indek terbaik yang ada di Bursa Efek Indonesia, mengingat hanya 45 perusahaan yang terbaik saja yang dapat masuk dalam indek ini.

Tujuan yang hendak dicapai dalam penelitian ini adalah untuk memperoleh bukti empiris bahwa: 1). Mengetahui pengaruh profitability terhadap capital structure perusahaan yang terdaftar di Indeks LQ-45; 2). mengetahui pengaruh firm size terhadap capital structure perusahaan yang terdaftar di Indeks LQ-45; 3). mengetahui pengaruh profitability terhadap Price book value perusahaan yang terdaftar di Indeks LQ-45; 4). mengetahui pengaruh firm size terhadap Price book value perusahaan yang terdaftar di Indeks LQ-45, dan 5) mengetahui pengaruh Capital Structure terhadap Price book value perusahaan yang terdaftar di Indeks LQ-45.

\section{TINJAUAN LITERATUR}

\section{Profitabilitas}

Banyak teori menyatakan bahwa modal meningkatkan kelangsungan hidup probabilitas bank/survival profitabiiltas bank (survival profitabily). Teori Repullo, (2004); Von Thadden, (2004) yang dikutip kembali oleh Berger, dan Bouwman, (2013) menekankan peran modal sebagai penyangga untuk menekan guncangan terhadap pendapatan perbankan. Berbagai teori lain menyatakan bahwa portofolio bank, skrining, dan pilihan pemantauan dipengaruhi oleh Struktur modal bank, jika mereka tetap ditahan, maka peran penyangga ini segera menyiratkan bahwa modal yang lebih besar dapat meningkatkan kelangsungan hidup probabilitas atau survival profitabilitas. Ini adalah efek mekanik modal yang lebih tinggi (besar). Teori lain lebih fokus pada efek insentif modal. Ini termasuk teori berdasarkan screening, monitoring, dan aset-substitusi moral hazard.

Profitabilitas dapat diukur dengan return on assets (ROA) dan ROE (return on equity). ROA menunjukkan kemampuan perusahan dengan menggunakan seluruh aktiva yang dimiliki untuk menghasilkan laba. Return on Assets (ROA) juga sering disebut Return on Investment (ROI) merupakan salah satu rasio profitabilitas yang mengukur efektifitas perusahaan dalam menghasilkan keuntungan dengan 
memanfaatkan aktiva yang dimilikinya. Indikator ROA merupakan salah satu indikator keuangan yang sering digunakan dalam menilai kinerja perusahaan. Jika kinerja perusahaan tersebut semakin baik, maka tingkat pengembalian (return) semakin besar. Rasio ini merupakan rasio penting diantara rasio rentabilitas profitabilitas yang lainnya. ROA atau ROI dapat diperoleh dengan cara membandingkan antara rasio laba usaha terhadap total aktiva. ROA menyatakan berapa besar profit yang mampu hasilkan ialah setiap rupiah aset yang ditanam atau investasikan (Suad Husnan, 2008).

ROE merupakan rasio laba bersih setelah pajak (earning after tax) setelah dikurangi deviden saham preferen terhadap modal sendiri. Karena rasio ini digunakan untuk menunjukkan berapa persen diperoleh laba bersih bila diukur dari modal sendiri. Oleh karena itu adalah wajar jika investor akan tertarik terhadap suatu saham yang memberikan return atau keuntungan yang besar. Jadi rasio ini sering dipakai oleh para investor dalam pengambilan keputusan pembelian saham suatu perusahaan. Jika rasio ini nilainya semakin optimal penggunaan modal sendiri suatu perusahaan dalam menghasilkan laba dan peningkatan laba berarti terjadi pertumbuhan dalam perusahaan. Semakin tinggi laba berarti semakin ingin saham tersebut diinginkan untuk dibeli. Sehingga akan menyebabkan permintaan akan meningkat dan selanjutnya harga saham akan naik. Dengan demikian ROE akan mempengaruhi perubahan harga, hal tersebut berpengaruh terhadap harga.

ROE mengukur kemampuan perusahaan menghasilkan laba berdasarkan modal saham tertentu. Rasio ini juga merupakan ukuran profitabilitas dari sudut pandang pemegang saham. Rasio ini tidak memperhitungkan deviden maupun capitel gain untuk pemegang saham. Karena itu Return on Equity (ROE) dapat dihitung dari:

$$
\mathrm{ROE}=\frac{\text { Laba Bersih }}{\text { Modal Sendiri }}
$$

Penelitian Goey lilian Oktaviani dan Marian ing Malelak (2014) menyatakan bahwa Profitabilitas tidak berpengaruh signifikan terhadap struktur modal perusahan. Dari temuan tersebut mengindikasikan bahwa orientasi dari profitabilitas pada periode sebelumnya pihak manajemen tidak menganggap dalam mempengaruhi keputusan dari struktur modal perusahaan dan penelitian Suryanata, Suwendra, dan Yudiaatmaja, (2014) yang menunjukkan bahwa terdapat pengaruh signifikan antara profitabilitas dengan nilai perusahaan.

Sedangkan Penelitian yang dilakukan Isabella Permata Dhani dan A.A Gde Satia Utama (2017), menyatakan bahwa pengaruh profitabilitas terhadap nilai perusahaan yang menganalisis dengan menggunakan model regresi berganda menyimpulkan bahwa profitabilitas berpengaruh signifikan terhadap nilai perusahaan dan penelitian yang berbeda dilakukan Sri Hermuningsih (2012), pengaruh profitabilitas dan zise terhadap nilai perusahaan dengan struktur modal sebagai variabel intervening menyatakan bahwa didalam penelitiannya profitabilitas berpengaruh positif signifikan terhadap struktur modal. 
H1 : Profitabilitas berpengaruh signifikan terhadap capital structure

H2 : Profitabilitas berpengaruh signifikan terhadap firm size

\section{Ukuran Perusahaan (Firm Size)}

Ukuran perusahan secara umum dapat diartikan sebagai suatu perbandingan besar atau kecilnya suatu objek yang menunjukkan besar atau kecilnya kekayaan yang dimiliki suatu perusahaan (Yulia, 2013). Gibson (1998:217) dalam Sambharakreshna (2010) menjelaskan "comparison of firm of different sizes may be more difficult than comparison of firms of equal size. For example, larger firms often have acces to wider and more sophisticated capital market, can buy in large quantities, and service wider markets." "be aware of the different sizes of firm sizes of firm under comparison. This differences can be seen by looking at relative sales, assets, or profit sizes." Ukuran perusahaan (firm size) menjelaskan tentang besar kecilnya suatu perusahaan, berdasarkan dari ukurannya tersebut dapat dilihat dari jenis-jenis usaha atau aktivitas usaha yang dilakukan oleh perusahaan. Penentuan besar kecilnya ukuran suatu perusahaan dapat dilihat berdasarkan total aset dan rata-rata total aset perusahaan. Perusahaan yang memiliki ukuran perusahaan yang besar cenderung memiliki total aset yang besar. Sehingga semakin besar ukuran perusahaan maka semakin besar pula profitabilitas, likuiditas, struktur aset dan pertumbuhan penjualan perusahaan.

Manfaat pengendalian manajemen adalah untuk menjamin bahwa organisasi telah melaksanakan strategi usahanya dengan efektif dan efisien. Dalam aspek finansial, penjualan dapat dilihat dari sisi perencanaan dan sisi realisasi yang diukur dalam satuan rupiah. Dalam sisi perencanaan, penjualan direfleksikan dalam bentuk target yang diharapkan dapat direalisir oleh perusahaan. Perusahaan dengan ukuran yang lebih besar memiliki akses yang lebih besar untuk mendapat sumber pendanaan dari berbagai sumber, sehingga untuk memperoleh pinjaman dari krediturpun akan lebih mudah karena perusahaan dengan ukuran besar memiliki probabilitas lebih besar untuk memenangkan persaingan atau bertahan dalam industri. Pada sisi lain, perusahaan dengan skala kecil lebih fleksibel dalam menghadapi ketidakpastian, karena perusahaan kecil lebih cepat bereaksi terhadap perubahan yang mendadak. Oleh karena itu, memungkinkan perusahaan besar tingkat leveragenya akan lebih besar dari perusahaan yang berukuran kecil (Hermuningsih, 2012). Dalam penelitian ini menggunakan nett sale dalam mengukur ukuran perusahaan. Nett sales diproxy dengan logaritma natural sebagai indikator ukuran perusahaan dikarenakan tingkat penjualan mampu mencerminkan ukuran perusahaan (Septiono, Suhadak, dan Darminto, 2011).

Ukuran perusahan secara umum dapat diartikan sebagai suatu perbandingan besar atau kecilnya suatu objek yang menunjukkan besar atau kecilnya kekayaan yang dimiliki suatu perusahaan (Yulia, 2013). Dalam penelitian ini menggunakan nett sale dalam mengukur ukuran perusahaan. Nett sales diproxy dengan logaritma natural sebagai indikator ukuran perusahaan dikarenakan tingkat penjualan mampu mencerminkan ukuran perusahaan (Septiono, Suhadak, dan Darminto, 2011). 
Ukuran Perusahaan $=\operatorname{Ln}($ Nett Sales $)$

Keterangan $L n \quad=$ Logaritma natural

Nett Sales $\quad=$ Penjualan bersih

Khumairoh, Kalbuana, dan Mulyati (2016), Sheikh dan Wang (2011) dan penelitian Hermunigsih (2012) yang menemukan pengaruh positif dari ukuran perusahaan pada struktur modal perusahaan. Penelitian Suryanata, Suwendra, dan Yudiaatmaja, (2014) yang menunjukkan bahwa terdapat pengaruh signifikan antara profitabilitas dengan nilai perusahaan sedangakan temuan berbeda oleh Fahri yulandani, Rina hartanti dan Susi dwimulyani (2018), dari hasil penelitian yang dilakukan bahwa tidak terdapat pengaruh yang signifikan antara variabel ukuran perusahaan (Size) terhadap perubahan variabel nilai perusahaan (PBV)

H3 : Firm size berpengaruh positif signifikan terhadap capital structure

H4 : Firm size berpengaruh positif signifikan terhadap Firm Value

\section{Capital Structure (Struktur Modal)}

Keputusan mengenai pemenuhan kebutuhan dana bersangkutan dengan penentuan sumber dana yang akan digunakan, penentuan perimbangan pembelanjaan yang terbaik atau penentuan struktur modal yang optimal (Van Horne, 1992) dalam Riyanto (2001: 10). Struktur modal (capital structure) merupakan komposisi pendanaan permanen perusahaan, yaitu bauran pendanaan jangka panjang perusahaan. Struktur modal merupakan bagian dari struktur keuangan dimana struktur keuangan mencerminkan kebijakan manajemen perusahaan dalam mendanai aktivanya (Sawir, 2004: 2).

Tujuan pokok manajemen struktur modal adalah menciptakan suatu bauran atau kombinasi sumber dana permanen sedemikian rupa agar mampu memaksimalkan harga saham perusahaan dan agar tujuan manajemen keuangan untuk memaksimalkan nilai perusahaan tercapai. Bauran pendanaan yang ideal dan selalu diupayakan manajemen ini disebut struktur modal optimal (Warsono, 2003: 235). Tujuan utama perusahaan adalah memaksimalkan kekayaan pemegang saham. Tujuan ini jelas bukan hanya menguntungkan pemegang saham, tetapi juga memastikan bahwa sumber daya yang terbatas telah dialokasikan secara efisien yang menguntungkan perekonomian. Kekayaan pemegang saham akan menjadi maksimal dengan memaksimalkan perbedaan antara nilai pasar saham dengan nilai buku saham bersangkutan. Ini dapat dicapai dengan membuat kebijakan struktur modal yang optimal, yaitu struktur modal yang meminimalkan biaya modal sehingga menjaga pengembalian atas investasi tetap tinggi.

Teori struktur modal menjelaskan apakah ada pengaruh perubahan struktur modal terhadap nilai perusahaan jika keputusan investasi dan kebijakan dividen dipegang konstan. Dengan kata lain, jika perusahaan menggantikan sebagian modal sendiri dengan hutang atau sebaliknya apakah harga saham akan berubah apabila perusahaan tidak mengubah keputusan-keputusan keuangan lainnya. Dengan kata lain, seandainya perubahan struktur modal tidak mengubah nilai perusahaan berarti bahwa tidak ada struktur modal yang terbaik. Semua struktur modal adalah baik, 
tetapi kalau dengan mengubah struktur modal ternyata nilai perusahaan berubah, maka akan diperoleh struktur modal yang terbaik. Struktur modal yang akan memaksimalkan nilai perusahaan adalah struktur modal yang terbaik (Husnan, 2004: 263).

Struktur modal dari segi teori berkenaan dengan bagaimana modal dialokasikan dalam aktifitas investasi aktiva riil perusahaan, dengan cara menentukan struktur modal antara modal hutang dan modal sendiri. Biasanya berkaitan dengan proyek proposal suatu investasi perusahaan dan tugas manajemen keuangan adalah menentukan struktur modal optimal untuk menunjang kegiatan investasi perusahaan. Dalam penelitian ini, peneliti menggunkan debt to equity ratio, dimana rasio ini digunakan untuk mengukur berapa besar ekuitas digunakan sebagai jaminan dalam membiayai hutang.

Sumber dana di dalam perusahaan dibagi ke dalam dua kategori, yaitu sumber pendanaan internal dan sumber pendanaan eksternal. Sumber pendanaan internal dapat diperoleh dari laba ditahan dan depresiasi aktiva tetap sedangkan sumber pendanaan eksternal dapat diperoleh dari para kreditur yang disebut dengan hutang.

$$
\text { DER }=\frac{\text { Total Utang }}{\text { Ekuitas }}
$$

Penelitian yang dilakukan oleh Andrian (2014) ada pengaruh signifikan antara variabel struktur modal terhadap variabel nilai perusahaan dan temuan Hermuningsih (2012), juga menyatakan pengaruh zise terhadap struktur modal didalam penelitiannya memiliki pengaruh yang positif signifikan. Profitabilitas dan ukuran perusahaan memiliki pengaruh tidak langsung terhadap nilai perusahaan dengan struktur modal sebagai variabel intervening. Sedang temuan berbeda penelitian Lubis, Sinaga, dan Sasongko (2017) yang menemukan bahwa DER berhubungan negatif dan tidak signifikan terhadap PBV.

H5 : Capital structure berpengaruh positif signifikan terhadap Firm value

\section{Kerangka Pemikiran Penelitian}

Kerangka pikir digunakan untuk memudahkan arah dalam penelitian. Dari uraian teori sebelumnya dapat digambarkan skema kerangka pemikiran sebagai berikut:

\section{Gambar 1. Kerangka Pikir Penelitian}

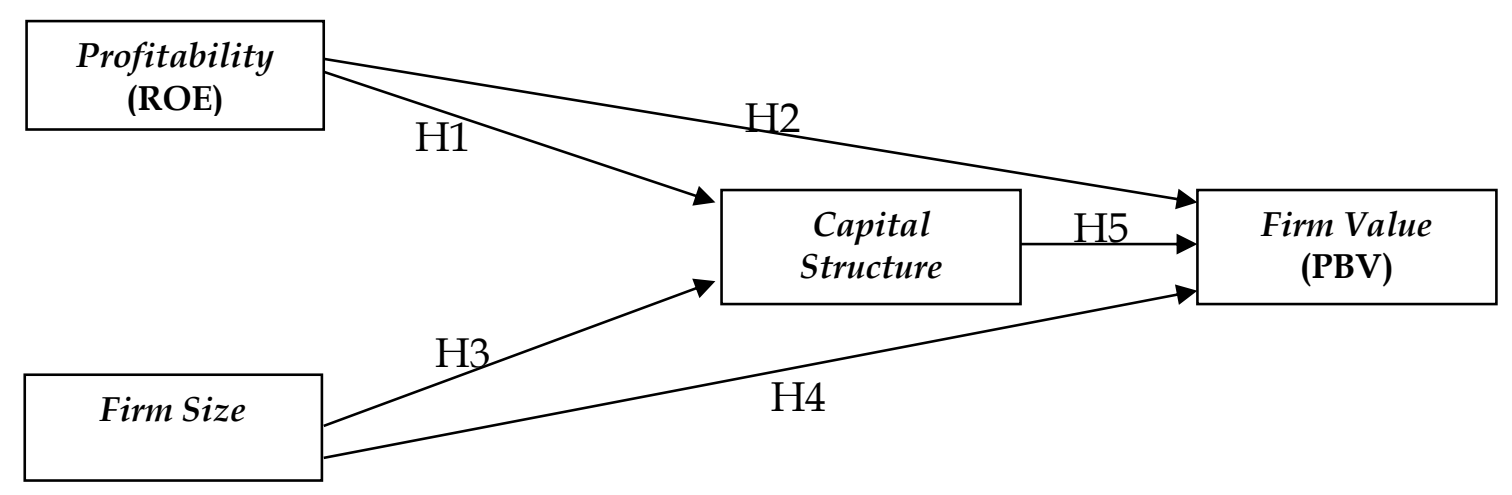


Sumber : Hermuningsih (2012), Oktaviani dan Malelak (2014), Khumairoh, Kalbuana, dan Mulyati (2016), Suryanata, Suwendra, dan Yudiaatmaja, (2014), Syeikh dan Wang (2011), Yulandani, Hartanti dan Dwimulyani (2018), dan Andrian (2014)

\section{METODE}

Penelitian ini menurut pendekatannya adalah penelitian kausal komparatif. Tujuan penelitian kausal-komparatif adalah untuk menyelidiki kemungkinan hubungan sebab-akibat dengan cara berdasarkan atas pengamatan terhadap akibat yang ada, mencari kembali faktor yang mungkin menjadi penyebab melalui data tertentu. Penelitian kausal-komperatif bersifat ex post facto. "Penelitian ex post facto adalah suatu penelitian yang mencoba menggali beberapa aspek dari objek penelitian dengan menggunakan instrumen yang telah disiapkan sebelumnya tanpa melakukan manipulasi variabel terhadap subjek yang diteliti" (Sugiyono, 2008: 7). Metode ex post facto digunakan untuk meneliti peristiwa yang telah terjadi dan kemudian merunut ke belakang untuk mengetahui faktor-faktor yang dapat menyebabkan timbulnya kejadian tersebut.

Obyek penelitian yang digunakan dalam penelitian ini adalah perusahaan yang masuk daftar indeks LQ-45 di Bursa Efek Indonesia tahun 2017 sedangkan Populasi dalam penelitian ini adalah seluruh perusahaan yang masuk daftar indeks LQ-45 di Bursa Efek Indonesia tahun 2017. Data dalam penelitian ini bersumber dari data sekunder (secondary data). Data sekunder adalah data yang diperoleh secara tidak langsung melalui media perantara. Data sekunder memiliki bentuk seperti bukti, catatan atau laporan histori yang telah tersusun dalam arsip (data dokumenter) yang dipublikasikan dan tidak dipublikasikan. Data sekunder yang digunakan berupa Laporan Keuangan Perusahaan-Perusahaan yang terdaftar di Bursa Efek Indonesia yang masuk dalam kategori LQ-45 yang secara khusus diambil dari Indonesian Capital Market Directory (ICMD) dan Annual Report pada tahun 2014 sampai bulan Agustus 2018 .

Dalam penelitian ini menggunakan analisis regresi linier berganda dengan menggunakan bantuan program GSCA. GSCA adalah metode baru berbasis komponen, sangat penting dan dapat digunakan untuk perhitungan skor (bukan skala) dan juga dapat diterapkan pada sampel yang sangat kecil. Seperti dinyatakan oleh Wold (1985) Partial Least Square (PLS) dan GSCA merupakan metode analisis yang powerfull oleh karena tidak didasarkan banyak asumsi. Data tidak harus berdistribusi normal multivariate (indikator dengan skala kategori, ordinal, interval sampai ratio dapat digunakan pada model yang sama), sampel tidak harus besar.

PLS dan GSCA dapat juga digunakan untuk mengkonfirmasi teori, tetapi dapat juga digunakan untuk menjelaskan ada atau tidaknya hubungan antar variabel laten. Oleh karena lebih menitik beratkan pada data dan dengan prosedur estimasi yang terbatas, maka mispesifikasi model tidak begitu berpengaruh terhadap estimasi paramater. Dibandingkan dengan CBSEM, Component Based SEM-PLS dan GSCA menghindarkan dua masalah serius yaitu inadmisable solution dan factor indeterminacy (Fornell dan Bookstein, 1982). 
Rumus Persamaan Model Struktural :

$$
\begin{aligned}
& \eta_{1}=\gamma_{1} \xi_{1}+\gamma_{2} \xi_{2}+\zeta_{1} \\
& \eta_{2}=\gamma_{3} \xi_{1}+\gamma_{4} \xi_{2}+\eta_{1} \beta_{1}+\zeta_{2}
\end{aligned}
$$

Di mana:

$\xi_{1}(\mathrm{Ksi}) \quad$ : Profitability (diproksikan oleh $\mathrm{ROE}$ ) sebagai variabel laten eksogen (bebas);

$\xi_{2} \quad:$ Firm Size sebagai variabel laten eksogen kedua (bebas);

$\eta_{1}($ Eta) : Capital Structure (diproksikan oleh DER) sebagai variabel laten endogen (terikat) pertama atau mediasi;

$\eta_{2} \quad$ : Firm Value (diproksikan oleh PBV) sebagai variabel laten endogen (terikat) murni atau variabel terikat kedua;

ү1.2,3.4 (Gamma) : Hubungan eksogen terhadap endogen;

$\beta_{1}$ (Beta) : Hubungan endogen terhadap endogen;

$\zeta_{1,2}$ (Zeta) : Measurement error persamaan struktural;

\section{HASIL DAN PEMBAHASAN}

\section{Measure of fit model}

Pengujian Goodness of Fit pada model penelitian di rangkum dalam tabel 1 yang menunjukkan hasil bahwa model telah FIT.

Tabel 1. Evaluasi Goodness-of-Fit

\begin{tabular}{ll}
\hline Indeks & Hasil \\
Model Goodness of Fit & Analisis \\
\hline FIT & 0,717 \\
AFIT & 0,707 \\
GFI & 0,996 \\
SRMR & 0,167 \\
NPAR & 13 \\
\hline Sumber diolah GSCA &
\end{tabular}

FIT

FIT menunjukkan varian total dari semua variabel yang dapat dijelaskan oleh model tertentu. Nilai FIT berkisar antara 0 - 1. Jadi model yang terbentuk dapat menjelaskan semua variabel yang ada sebesar 0,717. Profitabilitas, ukuran perusahaan, struktur modal dan nilai perusahaan yang dapat dijelaskan oleh model adalah sebesar $71,7 \%$ dan sisanya $(28,3 \%)$ dapat dijelaskan oleh variabel yang lain. Artinya jika dilihat dari nilai FIT yang diperoleh, model yang terbentuk dapat dikatakan baik. Semakin besar nilai FIT yang diperoleh maka model yang ada akan semakin baik.

\section{AFIT}

Nilai AFIT hampir sama dengan FIT. Namun, karena variabel yang mempengaruhi nilai perusahaan tidak hanya satu melainkan ada tiga variabel 
sehingga akan lebih baik apabila interpretasi tentang ketepatan model menggunakan FIT yang sudah terkoreksi dibandingkan menggunakan AFIT. Karena semakin banyak variabel yang mempengaruhi maka nilai FIT akan semakin besar karena proporsi keragaman juga akan meningkat sehingga untuk menyesuaikan dengan variabel yang ada dapat menggunakan FIT yang sudah terkoreksi. Jika dilihat dari nilai AFIT, profitabilitas, ukuran perusahaan, struktur modal dan nilai perusahaan yang dapat dijelaskan oleh model adalah sebesar 70,7\% dan sisanya (29,3\%) dapat dijelaskan oleh variabel yang lain.

\section{GFI}

Nilai cut off pada Unweighted least-squares (GFI) adalah $\geq 0,0$. Sehingga apabila nilai GFI diketahui $\geq 0,90$ maka model dapat dikatakan FIT. Pada permasalahan ini nilai GFI sebesar 0,996, sehingga model yang terbentuk dapat dikatakan cukup sesuai.

\section{SRMR}

Nilai cut off pada Standardized Root Mean square Residual (SRMR) adalah $\leq 0,08$. Sehingga apabila nilai SRMR diketahui $\leq 0,08$ maka model dapat dikatakan FIT. Hasil SRMR menunjukkan nilai 0,167 yang sebenarnya model dapat dikatakan belum sesuai karena belum mendekati 0 . Namun dikarenakan GFI atau SRMR hanya dipakai salah satu hasil yang terbaik, maka model yang diajukan dalam penelitian ini bisa dikatakan FIT.

\section{Pengujian Struktural (Hipotesis Penelitian)}

Pengujian analisis hipotesis dilakukan menggunakan metode Structural Equation Modeling (SEM) berbasis component atau variance (Component Based SEM) yang bersifat non-parametrik, yaitu: Generalized Structured Component Analysis (GSCA). Sebagai alternatif covariance-based SEM, pendekatan variance based atau component based dengan GSCA orientasi analisis bergeser dari menguji model kausalitas/teori ke component based predictive model (prediksi). Hasil pengujian hipotesis dalam penelitian menggunakan aplikasi GSCA diuraikan sebagai berikut:

Tabel 2 Hasil Pengujian Struktural

\begin{tabular}{|c|c|c|c|c|}
\hline Path Coefficients & & & & \\
\hline Hubungan Variabel & Estimate & SE & CR & Keterangan \\
\hline Profitability->Capital Structure & 0.967 & 0.396 & $2.44^{*}$ & Accepted \\
\hline Profitability->Firm Value & -0.248 & 0.588 & 0.42 & Rejected \\
\hline Firm size->Capital Structure & 0.083 & 0.068 & 1.21 & Rejected \\
\hline Firm size->Firm Value & -0.126 & 0.057 & $2.2^{*}$ & Accepted \\
\hline Capital Structure->Firm Value & -0.706 & 0.344 & $2.05^{*}$ & Accepted \\
\hline
\end{tabular}

Hasil pengujian struktural untuk menguji hipotesis pertama diperoleh hasil bahwa profitabilitas secara langsung berpengaruh signifikan pada structure modal, hasil tersebut ditunjukkan oleh perolehan nilai estimate sebesar 0,967 dengan nilai CR 
sebesar 2,44 > 1,96 (level signifikansi 5\% atau 0,05), atinya hasil penelitian ini diterima. Hal tersebut mengindikasikan bahwa profitabilitas merupakan variabel yang penting dalam mempengaruhi peningkatan struktur modal. Semakin tinggi/semakin baik nilai ROE maka akan dapat meningkatkan nilai DER secara langsung dan signifikan, begitupun sebaliknya apabila semakin nilai ROE rendah maka akan semakin menurunkan nilai DER secara signifikan pada perusahaan yang tergabung dalam indeks LQ-45. Hal ini tidak sependapat dengan hasil temuan dari Oktaviani dan Malelak (2014) yang mengatakan bahwa Profitabilitas tidak berpengaruh signifikan terhadap struktur modal perusahan.

Hasil penelitian ini mendukung hasil dari penelitian yang dilakukan oleh Suryanata, Suwendra, dan Yudiaatmaja (2014), dan Sri Hermuningsih (2012), bahwa profitabilitas berpengaruh positif dan signifikan terhadap struktur modal, yang menunjukkan bahwa perusahaan-perusahaan besar yang profitable lebih cenderung bersifat konservatif menggunakan hutang untuk operasi perusahaannya. Sementara untuk perusahaan yang kurang profitable cenderung tetap menggunakan dan internal telebih dahulu baru kemudian menutup kekurangannya dengan melakukan peminjaman dalam bentuk hutang.

\section{Pengaruh profitabilitas terhadap firm value}

Hasil pengujian struktural untuk menguji hipotesis kedua diperoleh hasil bahwa profitabilitas secara langsung berpengaruh signifikan pada nilai perusahaan, atinya hasil penelitian ini ditolak. Temuan penelitian menunjukkan hasil perolehan nilai estimate sebesar -0,248 dengan nilai CR sebesar 0,42<1,96 (level signifikansi 5\% atau 0,05$)$. Hal tersebut mengindikasikan bahwa profitabilitas bukan merupakan variabel penting dalam mempengaruhi penurunan nilai perusahaan secara langsung. Semakin semakin baik tingkat profitabilitas perusahaan belum dapat mempengaruhi secara langsung pada nilai perusahaan yang tergabung dalam indeks LQ-45. Hasil penelitian ini tidak sependapat dari hasil dari penelitian yang dilakukan oleh Dhani dan Utama (2017) menyatakan bahwa pengaruh profitabilitas berpengaruh signifikan terhadap nilai perusahaan.

\section{Pengaruh firm size terhadap capital structure}

Hasil pengujian struktural untuk menguji hipotesis ketiga diperoleh hasil bahwa ukuran perusahaan tidak berpengaruh signifikan pada struktur modal secara langsung, hasil tersebut ditunjukkan oleh perolehan nilai estimate sebesar 0,08 dengan nilai CR sebesar 1,21 < 1,96 (level signifikansi 5\% atau 0,05). Hal tersebut mengindikasikan bahwa ukuran perusahaan tidak berpengaruh signifikan dalam meningkatkan struktur modal secara langsung, atinya hasil penelitian ini ditolak. Variabel ukuran perusahaan bukan merupakan variable penting dalam mempengaruhi secara signifikan peningkatan struktur modal perusahaan. Besarkecilnya ukuran perusahaan tidak berpengaruh pada struktur modal perusahaan.

Hasil ini tidak sependapat dengan temuan yang dilakukan oleh Khumairoh, Kalbuana, dan Mulyati (2016), Sheikh dan Wang (2011) dan penelitian Hermunigsih (2012) yang menemukan pengaruh positif dari ukuran perusahaan pada struktur modal perusahaan. 


\section{Pengaruh firm size terhadap Firm Value (Nilai Perusahaan)}

Hasil pengujian struktural untuk menguji hipotesis keempat diperoleh hasil bahwa ukuran perusahaan dapat mempengaruhi nilai perusahaan secara signifikan langsung, diterima. Hasil tersebut dapat dilihat pada perolehan nilai estimate sebesar $-0,126$ dengan nilai CR sebesar 2,20 > 1,96 (level signifikansi 5\% atau 0,05). Hal tersebut mengindikasikan bahwa semakin besar ukuran perusahaan akan semakin menurunkan tingkat PBV secara signifikan. Hasil penelitian ini sependapat dari temuan oleh Suryanata, Suwendra, dan Yudiaatmaja, (2014) yang menunjukkan bahwa terdapat pengaruh signifikan antara profitabilitas dengan nilai perusahaan dan tidak mendukung dari temuan yang dilakukan oleh Yulandani, Hartanti dan Dwimulyani (2018) menyatakan bahwa ukuran perusahaan (Firm Size) terhadap variabel nilai perusahaan (PBV) tidak memiliki pengaruh yang signifikan.

\section{Pengaruh capital structure terhadap Firm Value}

Hasil pengujian struktural untuk menguji hipotesis kelima diperoleh hasil bahwa struktur modal perusahaan dapat mempengaruhi nilai perusahaan secara signifikan langsung, diterima. Hasil tersebut dapat dilihat pada perolehan nilai estimate sebesar -0,706 dengan nilai CR sebesar 2,05>1,96 (level signifikansi 5\% atau 0,05). Hal tersebut mengindikasikan bahwa semakin besar struktur modal perusahaan akan semakin berpengaruh pada penurunan nilai perusahaan yang diukur oleh PBV. Hasil penelitian ini sependapat dengan temuan Andrian (2014) dan Hermuningsih (2012), menyatakan pengaruh struktur modal terhadap nilai perusahaan memiliki pengaruh yang positif signifikan. Akan tetapi tidak sependapat dari temuan penelitian yang dilakukan oleh Lubis, Sinaga, dan Sasongko (2017) menemukan bahwa ahwa DER berhubungan negatif dan tidak signifikan terhadap PBV.

Tabel 3. R-square $\left(\mathbf{R}^{2}\right)$ Variabel Laten

\begin{tabular}{lc}
\hline R square of Latent Variable & \\
\hline Profitability & 0 \\
Firm size & 0 \\
Capital & 0.891 \\
Structure & 0.846 \\
Firm Value &
\end{tabular}

Hasil analisis yang terdapat pada Tabel 3 diketahui bahwa profitabilitas dan ukuran perusahaan dapat dijelaskan oleh struktur modal perusahaan sebesar 89,1\%. Nilai perusahaan dapat dijelaskan oleh profitabilitas, ukuran perusahaan dan struktur modal perusahaan sebesar $84,6 \%$, sedangkan sisanya dijelaskan oleh variabel diluar model/tidak diteliti. 


\section{SIMPULAN}

Berdasarkan dari hasil pengujian penelitian ini dengan pendekatan mengunakan kausal komparatif (ex post facto ) dengan pengujian analisis hipotesis yang dilakukan menggunakan metode Structural Equation Modeling (SEM) berbasis component atau variance (Component Based SEM) yang bersifat non-parametrik yaitu Generalized Structured Component Analysis (GSCA) dengan pendekatan variance based atau component based dengan GSCA pada perusahaan-Perusahaan yang terdaftar di Bursa Efek Indonesia yang masuk dalam kategori LQ-45 yang secara khusus diambil dari Indonesian Capital Market Directory (ICMD) dan Annual Report pada tahun 2014 sampai bulan Agustus 2018, menyatakan bahwa pertama profitabilitas secara langsung berpengaruh positif signifikan pada capital structure, Dari hasil temuan mengindikasikan bahwa orientasi dari profitabilitas pada periode sebelumsebelumnya bagi pihak manajemen dianggap penting dalam mempengaruhi keputusan dari capital structure perusahaan.

Temuan kedua menyatakan bahwa profitabilitas secara langsung berpengaruh positif signifikan pada frim value. Temuan penelitian menunjukkan hasil bahwa mengindikasi orientasi dari profitabilitas perusahaan dari periode sebelumsebelumnya bagi pihak manajemen menganggap penting juga dalam mempengaruhi keputusan dari frim value, Temuan ketiga menyatakan bahwa firm size tidak berpengaruh signifikan pada capital structure secara langsung, dari hasil temuan mengindikasikan bahwa firm size tidak begitu penting bagi komposisi pendanaan bagi pihak manajemen. Temuan keempat Firm size berpengaruh positif signifikan terhadap Firm Value, berdasarkan dari temuan dalam penelitian ini ukuran perusahaan yang dapat dilihat dari jenis-jenis usaha atau aktivitas usaha yang dilakukan oleh perusahaan tidak mempunyai arti dalam meningkatkan nilai perusahaan. Sedang temuan ke lima menyatakan bahwa capital structure berpengaruh signifikan terhadap Firm Value, Komposisi dari kombinasi sumber dana permanen dapat memaksimalkan harga saham perusahaan, capital structure menjadi salah satu unsur penting bagi manajemen keuangan dalam memaksimalkan nilai perusahaan.

Penelitian secara seluruhan menyatakan bahwa capital structure merupakan variabel intervening bagi pengaruh profitabilitas terhadap firm value, artinya capital structure memediasi pengaruh profitabilitas terhadap firm value secara full mediasi. Sedangkan capital structure merupakan bukan variabel intervening bagi pengaruh firm size terhadap firm value, artinya capital structure tidak memediasi pengaruh firm size terhadap firm value secara full mediasi. Hasil penelitian ini dapat menjadi pertimbangan bagi setiap perusahaan atau pengelola perusahaan dalam menentukan kebijakan-kebijakan perusahaan dimasa yang akan datang berkaitan dengan profitabilitas, firm value dan capital structure yang dapat mempengaruhi firm value perusahaan sehingga dalam tujuannya untuk meningkatkan nilai perusahaan tetap terjaga dan untuk bagi penelitian selanjutnya dapat menambahkan variabel-variabel lain yang dapat mempengaruhi firm value dengan capital structure sebagai variabel intervening yang belum dijelaskan dalam penelitian ini. 


\section{DAFTAR PUSTAKA}

Andrian, Jun. (2012). Pengaruh Struktur Modal, Pertumbuhan Perusahaan, Capital Expenditure dan Insentif Manajer Terhadap Nilai Perusahaan Dengan Profitabilitas Sebagai Variabel Intervening. Jurnal Bisnis Strategi 1. Vol. 21 No. 2 Desember 2012.

Berger, Allen N., and Bouwman, Christa H.S. (2013). How does capital affect bank performance during financial crises? Journal of Financial Economics 109 (2013) 146-176.

Dhani, Isabella permata dan Utama, A.A Gde satia. (2017). Pengaruh Pertumbuhan Perusahaan, Struktur Modal, Dan Profitabilitas Terhadap Nilai Perusahaan. Jurnal Riset Akuntansi dan Bisnis Airlangga Vol. 2 No. 1

Yulandani, Fahri; Hartanti, Rina; dan Dwimulyani, Susi (2018). Pengaruh Profitabilitas Dan Ukuran Perusahaan Terhadap Nilai Perusahaan Dengan CSR Sebagai Pemoderasi. Seminar Nasional I Universitas Pamulang Program Studi D3 Akuntansi.

Febriyani, Nina; dan Srimindarti, Ceacilia. (2010). Faktor-Faktor Yang Mempengaruhi Struktur Modal Pada Perusahaan-perusahaan LQ-45 Di Bursa Efek Indonesia Periode 2006-2008. Dinamika Keuangan dan Perbankan, Nopember 2010, Hal: 138 159 Vol. 2, No.2 ISSN :1979-4878 138.

Foyeke, Obigbemi Imoleayo; Olusola, Faboyede Samuel; and Aderemi, Adeyemo Kingsley. (2016). Financial Structure and the Profitability of Manufacturing Companies in Nigeria. Journal of Accounting, Finance and Auditing Studies 2/3 (2016) 56-63.

Oktiviani, Goey Lilian dan Malelak, Mariana Ing, (2014). Analisa Pengaruh Profitabilitas, Pertumbuhan, Struktur Aktiva, dan Ukuran Perusahaan Terhadap Keputusan Struktur Modal Perusahaan. FINESTA Vol. 2, No. 2, (2014)

Hermuningsih, Sri. (2012). Pengaruh Profitabilitas, Size Terhadap Nilai Perusahaan dengan Sruktur Modal Sebagai Variabel Intervening. Jurnal Siasat Bisnis. Vol. 16 No. 2, Juli 2012 232-242.

Husnan, Suad. (2009). Dasar-dasar Teori Portofolio dan Analisis Sekuritas. Edisi 4. UPP STIM YKPN. Yogyakarta.

Khumairoh, Nawang Kalbuana; dan Mulyati, Henny. (2016). Pengaruh Leverage, Profitabilitas, Dan Ukuran Perusahaan Terhadap Nilai Perusahaan. Prosiding Seminar Nasional dan The 3rd Call For Syariah Paper (SANCALL 2016) 
Lubis, M Sinaga, dan Sasongko. (2017). Pengaruh Profitabilitas, Sruktur Modal, Dan Likuiditas Terhadap Nilai Perusahaan, Jurnal aplikasi bisnis dan manajemen (JABM).

Sambharakreshna, Yudhanta. (2010). Pengaruh Size Of Firm, Growth Dan Profitabilitas Terhadap Struktur Modal Perusahaan. Universitas Trunojoyo. Jurnal Akuntansi, Manajemen Bisnis Dan Sektor Publik (Jambsp) Issn 1829-9857.

Septiono; Suhadak, Darminto. (2011). Analisis Faktor Mikro Terhadap Struktur Modal Dan Nilai Perusahaan (Studi Pada Perusahaan Non-Bank Yang Terdaftar Di Bursa Efek Indonesia Indeks Lq 45 Periode 2009-2011). Jurnal Administrasi Bisnis

Sheikh, Nadeem Ahmed; and Wang, Zongjun. (2011). Determinants of capital structure An empirical study of firms in manufacturing industry of Pakistan. Managerial Finance. Vol. 37 No. 2, 2011. pp. 117-133.

Suryanata, I Putu Sony; Suwendra, I Wayan; dan Yudiaatmaja, Fridayana. (2014). Tingkat Profitabilitas Bank Umum Swasta Nasional Devisa Yang Terdaftar di BEI Periode 2012-2013 (Kajian Faktor Penyebab dan Dampaknya). e-Journal Bisma Universitas Pendidikan Ganesha. Jurusan Manajemen (Volume 2 Tahun 2014)

Prijanto, Tulus; Veno, Andri; dan Chuzaimah. (2017). “Pengaruh ukuran perusahan dan likuiditas terhadap kinerja perusahaan.(Studi Empiris pada perusahaan manufaktur yang terdaftar di bursa efek Indonesia tahun 2013-2015)"Jurnal Akuntansi dan Sistem Teknologi Informasi Vol. 13 No 4 Desember 2017: 432 441. 